\title{
POTENSI Jatropha multifida TERHADAP JUMLAH FIBROBLAST PADA APHTHOUS ULCER MUKOSA MULUT TIKUS
}

\author{
Christina Destri $^{1}{ }^{1}$ I ketut Sudiana ${ }^{2}$, Jusak Nugraha ${ }^{3}$ \\ ${ }^{1}$ Jurusan S2 Imunologi Sekolah Pascasarjana Universitas Airlangga Surabaya \\ ${ }^{2}$ Departemen Patologi Anatomi, Fakultas Kedokteran, Universitas Airlangga Surabaya \\ ${ }^{3}$ Departemen Patologi Klinik, Fakultas Kedokteran, Universitas Airlangga Surabaya \\ Email: *1 christinadestri@gmail.com $^{1}$
}

\begin{abstract}
Abstrak
Peningkatan pemakaian obat dengan kandungan asli untuk lebih bebas efek toksik, mudah didapat dan harga yang terjangkau telah menjadi kebutuhan masyarakat dewasa ini. Jatropha multifida, dengan kandungan bioaktif alkaloid, flavonoid, saponin, tanin, dan diterpenoid berperan dalam penyembuhan luka. Tujuan penelitian untuk mengetahui potensi ekstrak Jatropha multifida terhadap jumlah fibroblast pada proses penyembuhan aphthous ulcer atau sariawan yang sering terjadi di masyarakat. Subyek penelitian adalah 24 ekor tikus Rat norvegicus dibagi menjadi kelompok KO (CMC-Na), P1 (JM 2,5\%); P2 (JM5\%), P3(JM10\%). Perlukaan pada mukosa mulut tikus dengan memakai burnisher yang dipanaskan dan ekstrak J.Multifida diberikan secara topikal 2 kali sehari selama 5 hari. Tikus dikorbankan dan dibiopsi incise pada hari ke-5. Untuk melihat jumlah fibroblast dilakukan pembuatan preparat dengan pengecatan Hematoxylin Eosin. Hasil: Terdapat perbedaan jumlah fibroblast secara signifikan pada hari ke-5 di KO (55,70), P1(69,60), P2(48,20), P3(65,53). Kesimpulan: ada perbedaan bermakna antara kelompok kontrol, P1 dan P2 dengan P3. Ektrak gel Jatropha multifida 5\% paling efektif terhadap jumlah fibroblast pada proses penyembuhan mukosa mulut tikus rat norvegicus.
\end{abstract}

Kata kunci : Aphthous ulcer, Jatropha multifida, fibroblast

\begin{abstract}
Increased use of drugs with the original content to be free of toxic effects, easily obtainable and affordable prices has become a necessity today's society. Jatropha multifida, with a content of bioactive components such as alkaloids, flavonoids, saponins, tannins, and diterpenoid play a role in wound healing. The aim of research to determine the potential of Jatropha multifida extract on the number of fibroblast in healing process of aphthous ulcers or sores that often occur in the community. Subjects were 24 rats were divided into groups of Rat norvegicus KO (CMC-Na 3\%), P1 (JM 2.5\%); P2 (JM5\%), P3 (JM10\%). Oral mucosal injury in rats using a heated burnisher and J.Multifida extract topically administered 2 times daily for 5 days. Mice were sacrificed and incision biopsied on day 5. To see the number of fibroblasts done making preparations with Hematoxylin eosin staining. Results: There were differences in the number of fibroblasts significantly on day 5 in KO (55.70), P1 (69.60), P2 (48.20), P3 (65.53). Conclusion: There were significant differences between the control group, P1 and P2 to P3. Gel extracts of Jatropha multifida $5 \%$ most effective against the number of fibroblasts in the healing process norvegicus rat rat oral mисоsa.
\end{abstract}

Keywords: Fibroblast, Aphthous ulcers, Jatropha multifida. 


\section{PENDAHULUAN}

Aphthous ulcer atau aphthous stomatitis dikenal sebagai sariawan di kalangan masyarakat Indonesia merupakan penyakit rongga mulut yang paling umum terjadi. Aphthous ulcer diklasifikasikan sebagai ulcer minor, mayor dan herpetiform. Lebih dari $85 \%$ apthous ulcer adalah bentuk minor dengan diameter kurang dari $1 \mathrm{~cm}$. Kejadian apthous ulcer cenderung lebih banyak terjadi pada wanita $(67,4 \%)$ dibandingkan pria $(22,6 \%)$ dengan lokasi ulcer banyak ditemukan pada area bibir $(35,7 \%)$ (Ronald G. Shahsy et al., 2000; Anabel Diaz et al., 2015). Proses inflamasi memainkan peran penting karena rasa sakit yang terjadi pada apthous ulcer disebabkan inflamasi yang berlebihan dan psikokimia akibat iritasi ujung saraf efferent yang berhubungan dengan lapisan epitel dan sub epitel (Xiao Wen Jiang et al., 2013). Faktor trauma paling banyak menyebabkan pembentukan ulcer pada satu individu sehingga timbul kematian transepithelial yang bersifat apoptosis masiv dan mendadak diikuti timbulnya secondary necrosis yang mengarah pada pelepasan danger signal dari sel epitel sehingga terjadi pengelupasan lapisan sel epitel mati dan terbentuklah ulcer (Al Samadi, 2015). Aphthous ulcer merupakan ulcer pada mukosa buccal yang ditutup eksudat fibropirulent dan infiltrasi non spesifik kronis yang berbatasan dengan lamina propria (Stephen T. Sonis, 2015). Secara klinis bentukan aphthous ulcer terlihat bulat atau oval dangkal, terasa sangat sakit dan terlihat batas kemerahan karena peradangan akut pada mukosa mulut (bibir, buccal dan lingual)(Ronald G. Shahsy,2000). Anestesi topikal Lidocaine 2\%, Benzocaine dan Benzydamine Hydrochloride hanya akan mengurangi rasa sakit dalam waktu singkat (Sunday O., 2014).

Dalam beberapa tahun terakhir terjadi peningkatan penggunaan obat dengan kandungan asli karena dianggap efek toksik yang lebih kecil dan khasiat yang lebih baik. Lebih dari itu peningkatan resistensi antibiotik secara konstan dan berbagai efek samping dari obat sintetis mendorong pengobatan herbal dipercaya bisa meningkatkan ketahanan alami tubuh dimana aktifitas imunomodulator telah banyak ditemukan dalam tanaman (Shruti Shukla, 2012). Jatropha multifida dikenal sebagai tanaman betadine karena dikenal mampu untuk mengobati luka. Diketahui bahwa bagian dari daun, akar, biji dan batang dari tanaman ini mengandung secondary metabolite seperti alkaloid, tanin, flavonoid, saponin dan phenol (Nwokocha et al., 2011). Berdasarkan pengalaman empiris, tanaman ini dapat digunakan sebagai obat tradisional untuk obat luar seperti luka baru dan untuk mengobati berbagai jenis infeksi dengan langsung mengoleskan getah Jatropha multifida Linn pada luka tersebut. Getah dan daunnya juga digunakan untuk menyembuhkan infeksi pada lidah bayi (Adesola A, Adetunji O,2007). Penggunaan Jatropha multifida untuk proses penyembuhan aphthous ulcer masih belum banyak diteliti, sehingga penelitian ini bertujuan menganalisis potensi Jatropha multifida terhadap jumlah fibroblast terhadap ulcer pada mukosa mulut tikus Rat norvegicus.

\section{TINJAUAN}

\subsection{Aphthous Ulcer}

Apthous ulcer diklasifikasikan sebagai ulcer minor, mayor dan herpetiform. Lebih dari $85 \%$ aphthous ulcer adalah bentuk minor dengan diameter kurang dari $1 \mathrm{~cm}$. Aphthous ulcer bentuk mayor dikenal sebagai Sutton Disease atau periadinitis mucosa necrotica recurrence dengan diameter lebih dari $1 \mathrm{~cm}$ dan dapat berlangsung selama beberapa minggu bahkan beberapa bulan. Aphthous ulcer bentuk herpetiform secara klinis terlihat berbeda karena ulcer yang ditimbulkan berupa klaster atau multiple dan didapati hampir di semua bagian rongga mulut (Akintoye SO, 2014). Aphthous ulcer bentuk minor merupakan ulcer yang paling banyak terjadi (80\%-90\%) dibandingkan dengan dua tipe yang lain. Kejadian aphthous ulcer cenderung lebih banyak terjadi pada wanita $(67,4 \%)$ dibandingkan pria $(22,6 \%)$ 
dengan lokasi ulcer banyak ditemukan pada bibir $(35,7 \%)$

Hal yang paling banyak memicu terjadinya aphthous ulcer adalah faktor trauma karena tergigitnya bagian bibir atau pipi, abrasi dari makanan yang keras, proses pada waktu menyikat gigi maupun pada waktu penggunaan alat-alat kedokteran (Ronald G. Shahsy et al., 2000).

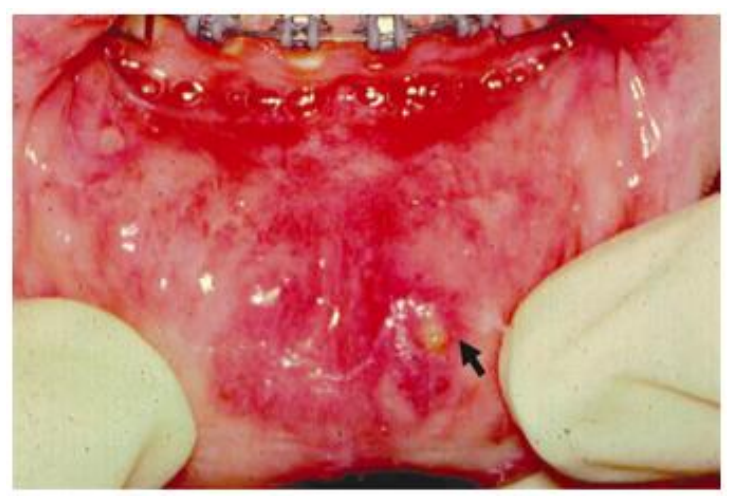

Gambar 1. Minor aphthous ulcer

Faktor trauma lokal cenderung menyebabkan pembengkakan dan inflamasi seluler yang berasosiasi dengan peningkatan viskositas ekstraselular matriks dari sub mukosa mulut. Ulcer berkembang pada mukosa mulut non keratin dengan bagian buccal dan mukosa labial sebagai tempat paling umum terjadi (Akintoye SO, 2014).

\subsection{Sistim Imunitas Rongga mulut}

Keratinosit pada mulut dan sel dendrit pada mukosa mulut melalui molecular recognition receptor mampu membedakan antara mikroorganisme komensal dan patogenik dengan memediasi dihasilkannya respon perlindungan berupa imun inflamasi terhadap invasi patogen atau sebagai media imun toleran terhadap mikroorganisme komensal. Imun toleran di dalam rongga mulut merupakan hasil dari kurangnya aktifitas respon sel $\mathrm{T}$ terhadap presentasi antigen yang imunogenik atau ditekannya aktifitas sel $\mathrm{T}$ efektor oleh sel T regulator. Sekresi IgA di dalam rongga mulut berkontribusi dengan membatasi kolonisasi dan invasi mikroorganisme terhadap sel epitelium. Tergantung atau tidaknya switching Ig isotipe ke IgA terhadap sel thelper akan difasilitasi oleh sekresi sitokin dari sel dendrit atau monosit.
Imunitas mukosa mulut mampu menetralisir antigen asing yang berbahaya, membatasi kolonisasi mikroorganisme patogen, sebagai mediator yang menghasilkan respon perlindungan imunoinflamasi dan memediasi toleransi terhadap mikroorganisme komensal dan soluble antigen non-self yang berasal dari berbagai protein eksogeneous.

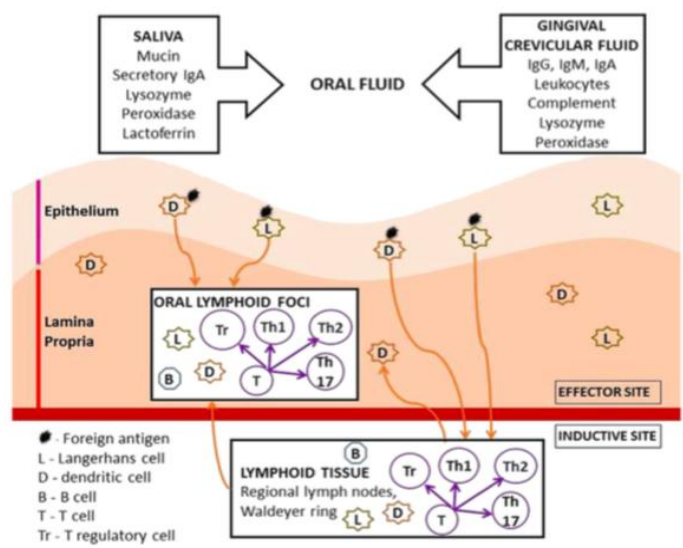

Gambar 2. Imunitas rongga mulut

Saliva yang mengandung $\operatorname{IgA}$, mucin dan enzim akan melindungi mukosa mulut dari kolonisasi bakteri. Gingival crevicular fluid yang menjangkau rongga mulut mengandung likosit, $\operatorname{IgM}$ dan $\operatorname{Ig}$ A serta berbagai agen yang berkontribusi dalam imunitas rongga mulut. Sel Langerhans dan sel dendrit myeloid lain setelah menangkap antigen asing akan bermigrasi ke regional nodus limpa untuk dipertemukan dengan sel imun efektor. Sel imun efektor akan bermigrasi ke lamina propria dimana sel akan memediasi aktifitas respon imun atau imun toleran (Feller et al., 2013).

\subsection{Proses Penyembuhan Ulcer}

Ulcer merupakan luka terbuka pada kulit, mukosa dan membrane mukosa yang seringkali disebabkan karena abrasi dan secara umum menimbulkan peradangan dengan atau tanpa infeksi (Christian A., 2015).

Proses penyembuhan luka pada jaringan lunak di dalam rongga mulut mempunyai prinsip yang sama dengan bagian tubuh lain misalnya kulit. Penyembuhan luka selalu diawali dari proses pembekuan darah yang 
mempunyai tujuan untuk menutup luka (Hannu Larjava, 2012).

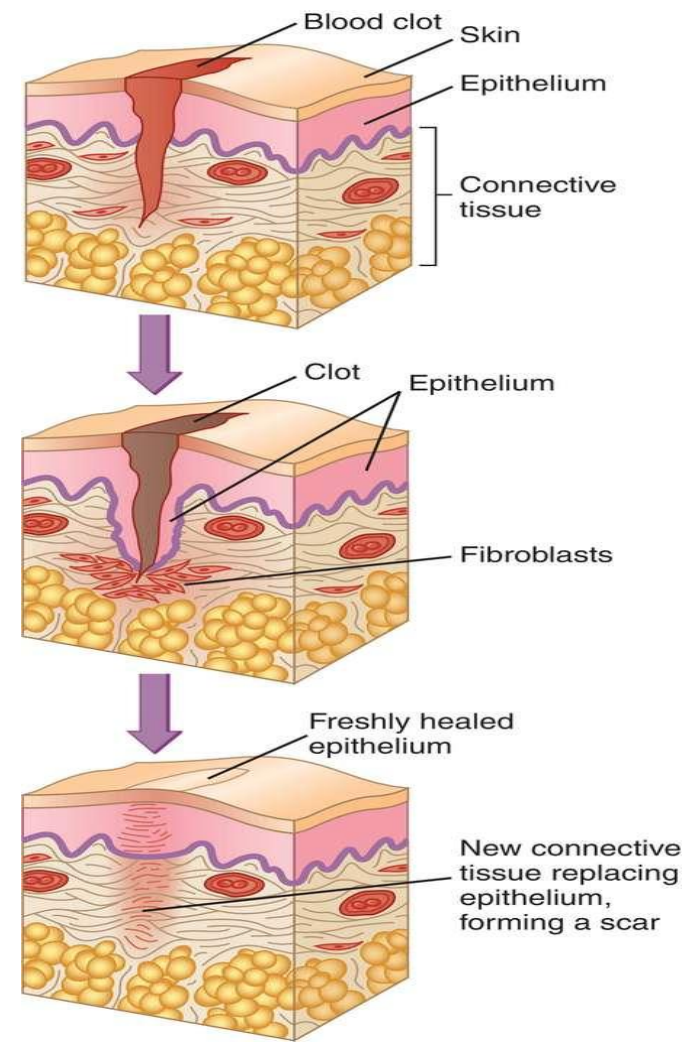

Gambar 3. Proses penyembuhan luka

Penyembuhan luka merupakan suatu rangkaian proses dengan dinamika yang tinggi dan tepat, terdiri dari tahapan yang saling mengikuti. Diawali dari tahap inflamasi, proliferasi sel, deposisi matrik hingga fase remodeling. Semua fase perbaikan termasuk fase inflamasi, re-epitelisasi dan pembentukan granulasi jaringan merupakan bagian yang dipengaruhi secara komplek oleh growth factor dan sitokin yang secara langsung mengarah ke area luka (Sule Coskun et al., 2007).

Pada kaskade penyembuhan luka secara normal, proses yang terjadi selalu diawali dengan proses hemostasis dan deposisi fibrin yang kemudian mengarah pada kaskade sel-sel inflamasi yang dikarakterkan oleh netrophil, makrofage, dan limposit. Proses ini kemudian diikuti dengan penarikan dan proliferasi fibroblast, dilanjutkan dengan penumpukan dan remodeling kolagen hingga terjadi pematangan bekas luka (Robert F. Diegelmann, 2004).

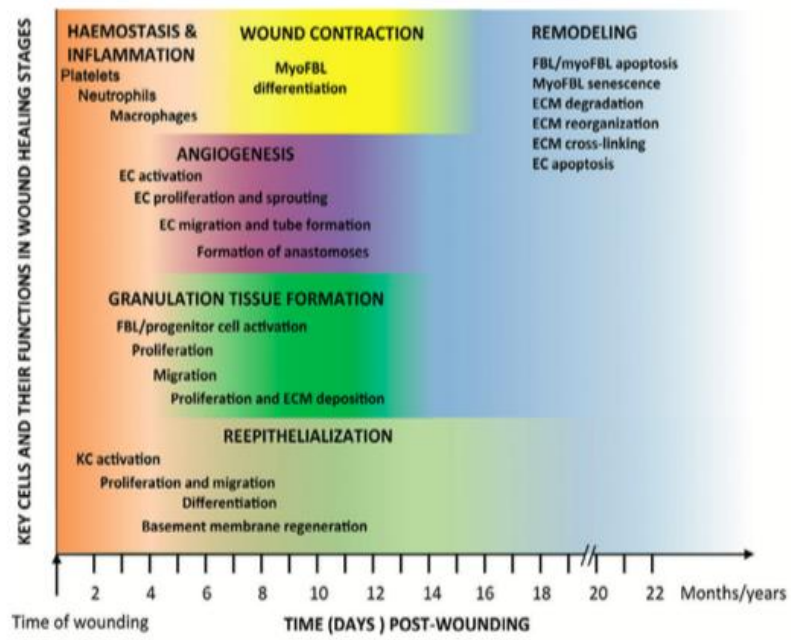

Gambar 4. Skema peran sel dan fungsi dalam proses penyembuhan luka

\subsection{Fase Hemostasis}

Penyembuhan luka selalu diawali dengan pembekuan darah sebagai hal awal untuk menutup luka. Aktivasi trombosit selama hemostasis akan melepaskan sejumlah sitokin penting yang mengawali proses penyembuhan melalui signal kemotaktik yang ditujukan kepada sel-sel inflamasi dan sel residen. Selain itu bekuan fibrin fibronektin berperan sebagai provisional matrik dari sel epitel dan fibroblast untuk dapat migrasi menuju area luka. Pelepasan sitokin selama fase pembekuan mengawali reaksi inflamasi sebagai penyedia debridement dengan menghilangkan jaringan yang rusak dan mikroba. Selama proses respon imun innate ini terjadi sel-sel inflamasi yang telah direkrut pada area luka akan melepaskan lebih banyak lagi sitokin dan kemokin yang berfungsi untuk memodulasi penyembuhan luka. Makrofage merupakan sel yang paling penting pada perbaikan luka. Sel makrofage mensekresikan vascular endothelial growth factor (VEGF), Fibroblasts growth factor (FGF) dan Transforming growth factor (TGFB) yang merupakan regulator paling signifikan untuk perbaikan jaringan (Hannu Larjava, 2012). 


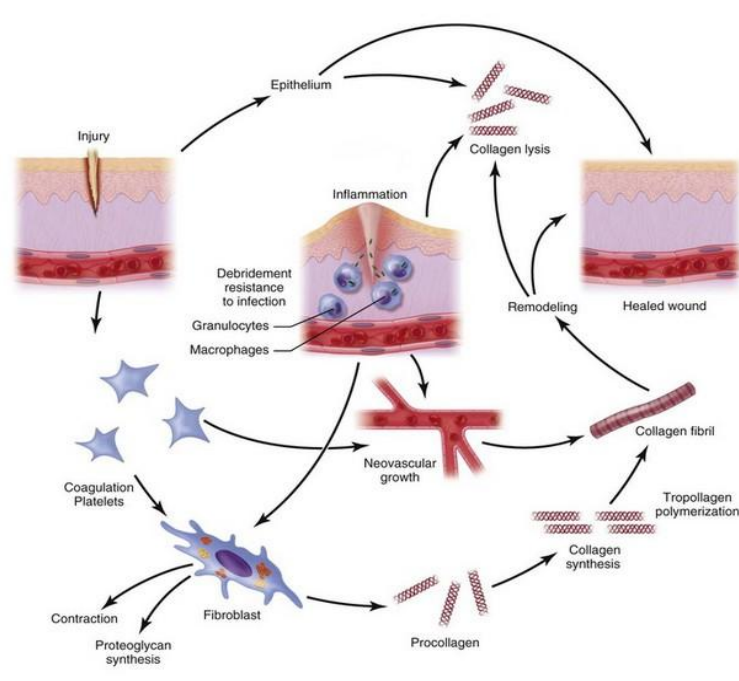

Gambar 5. Overview penyembuhan luka

Luka pada jaringan akan mengeluarkan ADP yang menyebabkan trombosit melekat pada permukaan luka terbuka. Hal ini akan mengaktifkan kaskade hemostasis yaitu dengan memproduksi trombin yang akan merubah fibrinogen menjadi fibrin sehingga terbentuk sumbat hemostasis yang stabil. Selain itu juga disekresikan sitokin Fibroblast growth factor (FGF), Tranforming growth factor - Beta (TGF-B), Platelet derived growth factor (PDGF) dan Epidermal growth factor (EGF) sebagai mekanisme kemotaktik sehingga netrophil dan monosit bergerak kea rah luka untuk memulai fase inflamasi (Christian Agyare et al., 2015)

\subsection{Fase Inflamasi}

Fase inflamasi dimulai saat netrophil melekat pada endothelium sesaat setelah trauma. Netrophil dengan elastse dan kolagenase memfasilitasi migrsi menuju bagian ekstra selular dimana sel akan memfagositosis bakteri, degradasi matrik protein serta menarik penambahan netrophil dan makrofage. Sel inflamasi yang paling berperan yaitu sel makrofage akan mendominasi area luka dari hari ke-3 hingga hari ke-5. Makrofage akan memfagositosis organisme patogenik, degradasi debris dari luka dan menstimulasi pembentukan granulasi jaringan serta angiogenesis. Growth factor dari makrofage antara lain platelet derived growth factor, transforming growth factor, fibroblast growth factor, IL-1, IL-6 dan tumor necrosis factor (Laurel M.Morton, 2016).

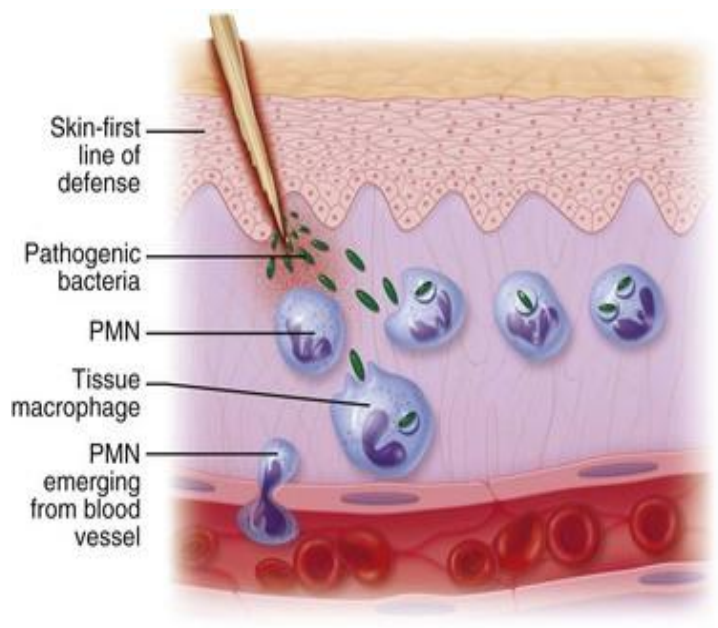

Gambar 6. Fagositosis PMN

Dimulai pada 6-8 jam setelah luka, pembuluh darah yang rusak akan mengeluarkan plasma dan netrophil ke area luka. Netrophil akan mulai mencerna dan membersihkan sel debris dan se lasing sehingga netrophil akan mengalami apoptosis dan perannya digantikan oleh makrofage. Produk makrofage akan menstimulasi sel endotel untuk berproliferasi. Degradasi produk fibrin akan berfungsi sebagai kemotaktik sel fibroblst dan sel epitel ke area luka (Christian Agyare, 2015).

\subsection{Fase Proliferasi}

Fase proliferasi meliputi fibroplasia, granulasi, epitelisasi dan angiogenesis yang dimulai 24 jam setelah trauma. Matrik fibrin sebagai tempat migrasi keratinosit dimana sebagian sel ini distimulasi oleh TGF-B akan bergerak dari tepian luka dan folikel rambut menggeser keratinosit yang telah ada di area luka dengan melompat. Dalam waktu yang sama VEGF diinduksi oksigen yang rendah akan mempromosi angiogenesis dan mempengaruhi sel endotel kapiler terdekat untuk direkrut dan distimulasi untuk berproliferasi. Platelet derived growth factor 
mengatur fibroblast yang bermigrasi 48 jam hingga 72 jam setelah terjadi luka untuk mengalami proliferasi matrik dermal (Laurel M.Morton, 2016).

Fase proliferasi dimulai rata-rata hari ke-4 setelah luka dan berlangsung hingga hari ke21 pada luka akut, tergantung pada ukuran luka dan kesehatan penderita. Fibroblast dan sel endotel merupakan sel kunci yang berperan penting untuk proses terjadinya angiogenesis, proliferasi fibroblast (deposisi kolagen), pembentukan jaringan granulasi, kontraksi luka dan re-epitelisasi yang diikontrol oleh FGF, TGF-B dan VEGF.

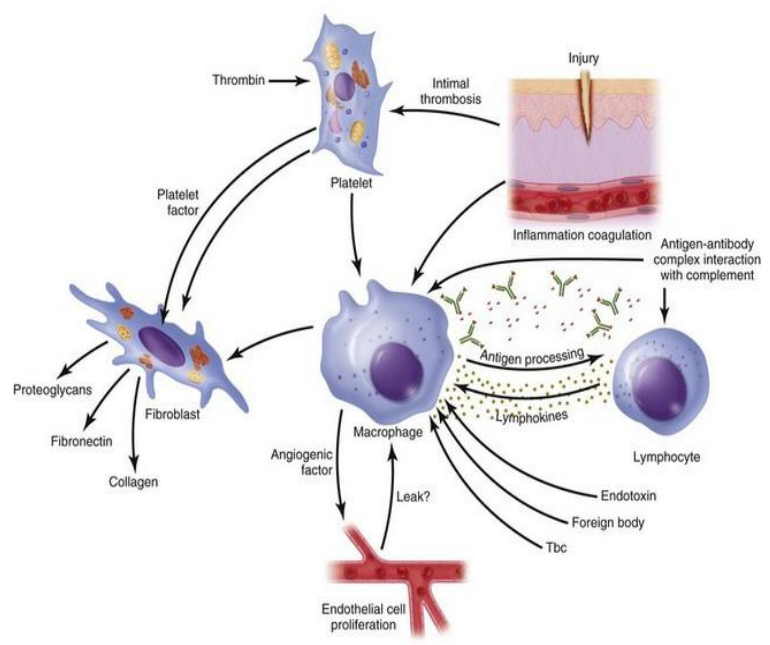

Gambar 8. Interaksi sel kearah penyembuhan luka

\subsection{Fase Remodeling}

Fase remodeling membutuhkan waktu beberapa minggu hingga tahun. Kontraksi luka dimulai hari ke-5 karena adanya perubahan fenotip fibroblast menjadi actin-laden myofibroblast (Laurel M.Morton, 2016).

Proses kontraksi akan menarik tepian luka untuk saling mendekat, mengurangi area permukaan dan meningkatkan kecepatan penutupan luka. Kontraksi luka secara aktif dimediasi oleh myofibroblast yang berdifferensiasi dengan menggunakan reseptor integrin untuk menarik matrik memakai kekuatan sitoskeleton yang kaya dengan aktin. Myofibroblast berdiferensiasi dari residen fibroblast lokal atau sel progenitor lain dengan molekul matrik tertentu dan growth factor seperti EDA-fibronektin dan TGF-B. setelah terjadi kontraksi luka maka remodeling dilakukan oleh jaringan granulasi. Selama proses berlangsung terjadi degradasi fibroblast dan remodeling Extra Cellular Matrix (ECM). perubahan signal mekanosensori dari jaringan remodeling akan mengurangi aktifitas selular, produksi matrik berhenti dan myofibroblast mengalami apoptosis. Di beberapa bagian dari mukosa mulut (gingiva, mucosa palatal) hasil penyembuhan secara klinis terlihat tanpa bekas luka dengan fitur histologi yang hampir semuanya normal (Hannu Larjava, 2012).

\section{Remodeling Phase}

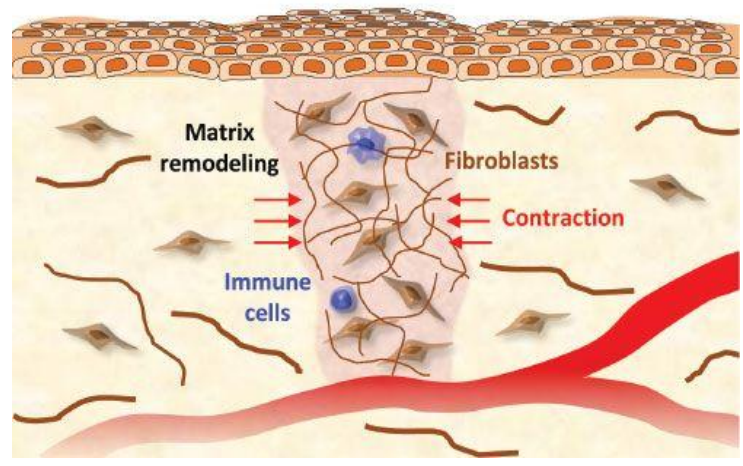

Gambar 9. Fase remodeling

Fase perbaikan dari proses penyembuhan luka seperti morfogenesis jaringan meliputi berbagai proses selular termasuk diantaranya adalah migrasi sel, proliferasi, diferensiasi dan apoptosis. Dari berbagai bukti diketahui bahwa Matrix Metalloproteinase (MMP) merupakan regulator positif dari proses yang terjadi di fase ini, dan diketahi pula bahwa MMP 2 dan MMP 9 mempunyai efek menghambat dari proliferasi sel.

Fungsi lain dari MMP yaitu degradasi ECM selain sebagai bagian yang memproses molekul bioaktif seperti growth factor, sitokin, kemokin serta reseptor. Kemampuan degradasi ECM dilakukan oleh MMP antara lain MMP1, MMP3, MMP 13, MMP 14 yang mampu memecah kolagen dan MMP 7 yang dapat memproses Syndecan 1 dan elastin. 
Proses penyembuhan merupakan proses yang komplek dan memerlukan keadaan yang tepat untuk suatu hubungan yang mengekspesikan signaling molekul dan reseptor, molekul adhesi selular dan protein ECM. MMP dan inhibitornya mampu melakukan berbagai proses dari signaling molekul (Sean E. Gill, 2008).

\subsection{Peran Fibroblast}

Fibroblast terdapat di berbagai jaringan pengikat dengan berbagai populasi sel yang heterogen. Secara struktur fibroblast banyak mengandung rough endoplasmic reticulum dan golgi aparatus yang merupakan karakter sel dengan aktifitas biosintesis yang tinggi. Fibroblast merupakan sumber utama dari protein Extra Cellular Matrix terutama bentuk kolagen dan fibronektin yang merupakan bentuk granulasi jaringan dan berperan dalam penyediaan integritas struktural pada luka. Bentuk spesifik fibroblast adalah myofibroblast yang merupakan sumber penyokong kekuatan kontraksi dan berperan penting serta efisien untuk penutupan luka (Ian A. Darby, 2007).

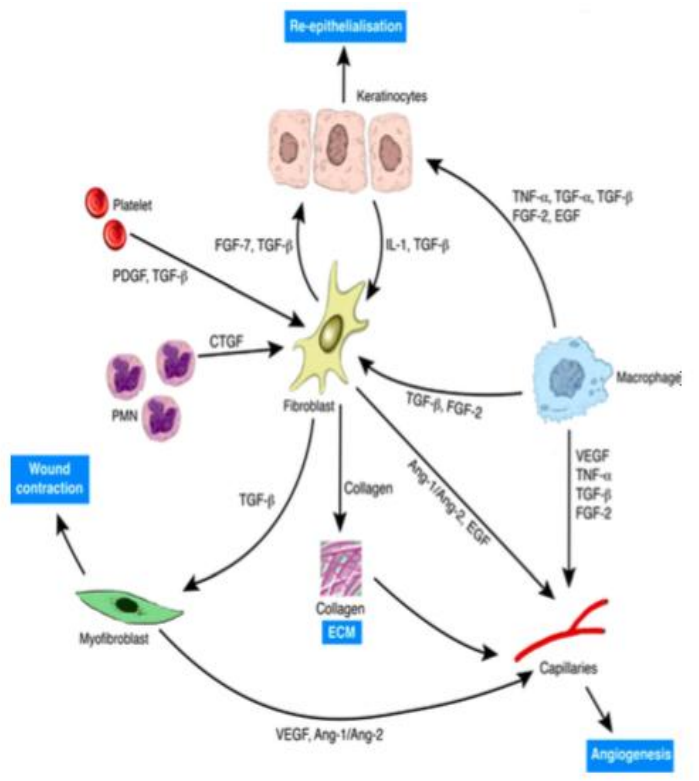

Gambar 10. Interaksi berbalasan dari berbagai tipe sel dengan sel fibroblast secara signifikan mempengaruhi proses penyembuhan luka.
Fibroblast berada selama proses penyembuhan luka dimulai dari akhir fase inflamasi hingga fase epitelisasi selesai. Akhir fase inflamasi dan awal fase proliferasi (24-48 jam setelah luka) merupakan awal fibroblast terlihat pada area luka. Infiltrasi dan degradasi dari bekuan fibrin bersal dari fibroblast yang mensekresi beberapa jenis matrix metalloproteinase dan mengganti komponen extra cellular matrix seperti kolagen, glikoprotein, proteoglikan, laminin, trombospondin, glikosaminoglikan, hyaluronic acid dan heparin sulphate. Kompleks matrik akan mendukung dan mengatur migrasi serta aktifitas fibroblast, support signal untuk angiogenesis, pembentukan jaringa granulasi dan terjadinya epitelisasi.

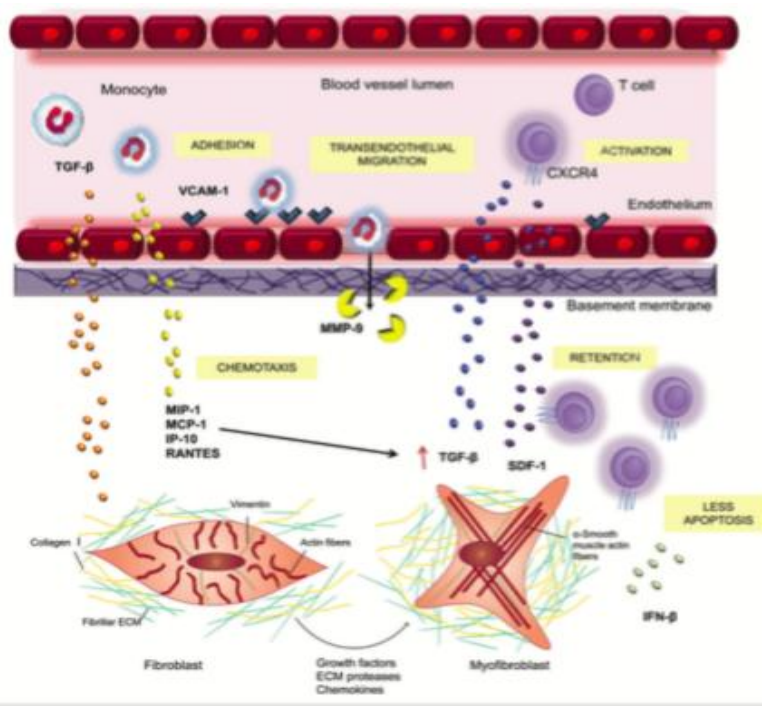

Gambar 11. Peran aktif fibroblast di faseInflamasi. Myofibroblast mengaktifkan lekosit untuk memproduksi gelatinase MMP 9 untuk degradasi membrane basal diikuti dengan migrasi sel endotel.

Fibroblast yang telah sampai di area luka akan berkurang aktifitasnya, terjadi perlekatan di bekuan fibrin dan dasar luka melalui multiple integrin. Fibroblast segera berproliferasi dan memproduksi MMP serta proteinase yang lain seperti seperinase yang digunakan untuk denaturasi protein dan provisional matrik yang tidak diperlukan lagi untuk proses penyembuhan luka. Proteinase dikontrol ketat oleh tissue inhibitor of metalloproteinase (TIMP) yang diproduksi oleh fibroblast. Produksi ECM yang baru 
relatif kaya dengan kolagen III, fibronektin dan hyaluronic acid. Degradasi kembali oleh protease dilakukan untuk remodeling sehingga fibroblast akan mengganti kolagen tipe III ke tipe kolagen I yang mempunyai kekuatan tensile lebih tinggi meskipun diperlukan beberapa waktu untuk terjadinya deposisi.

Fibroblast merupakan kunci untuk dapat terjadinya penyembuhan luka secara normal. Apabila fibroblast tidak teraktifasi atau migrasi ke provisional matrik tidak optimal maka autolisis debridement dari denaturasi protein dan pembentukan sumbat fibrin akan berkurang. Aktifitas penting dari fibroblast adalah kontribusi sel untuk produksi extra cellular matrix dan kontraksi sel pada proses penyembuhan luka (P. Bainbridge, 2014).

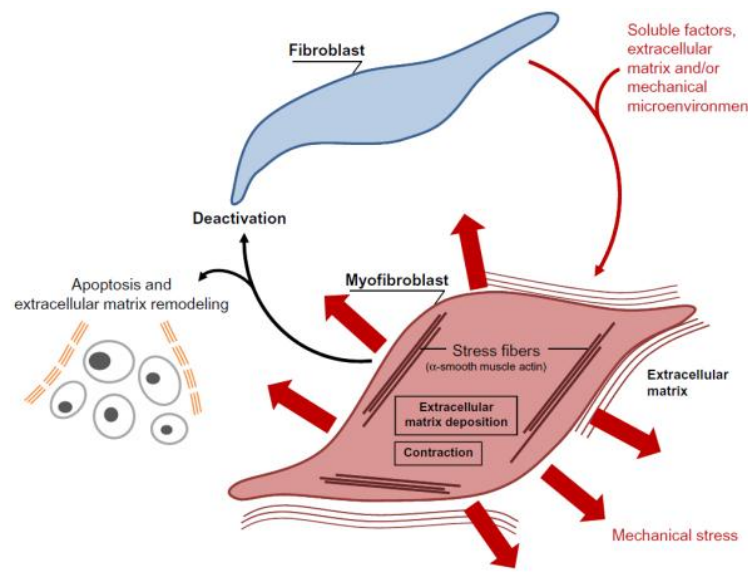

Gambar 12. Skematik evolusi fenotip myofibroblast

\subsection{Jatropha multifida Linn}

Perkembangan resistensi antibiotik mikrobial menjadi pencarian global untuk antimikroba dengan kemurnian alami seperti pada tanaman asli. Jatropha multifida merupakan tumbuhan tahunan berbentuk semak dengan tinggi 2-3 meter. Jatropha bersal dari bahasa Yunani "jatros" yang berarti dokter dan "trophe" berarti makanan. Tumbuhan ini banyak ditemukan di daerah tropis, Afrika bagian tropis serta beberapa daerah sub-tropis seperti Afrika Utara, Madagskar, Mauritius, Afrika, Asia dan Amerika Latin telah menggunakan spesies
Jatropha sebagai tumbuhan obat tradisional untuk mengobati berbagai penyakit (Silma R. et al., 2014)

Di Jawa timur, Jatropha multifida dikenal sebagai tanaman yodium. Nama umum di Indonesia dikenal dengan nama Jarak tintir, Jarak gurita atau Jarak cina. Di Philippina dikenal sebagai tumbuhan Mana, Manaku (Malaysia), Kuthirnevala (Thamil) dan Bhadradanti (Sansekerta) (S. Kosasih et al., 1989).
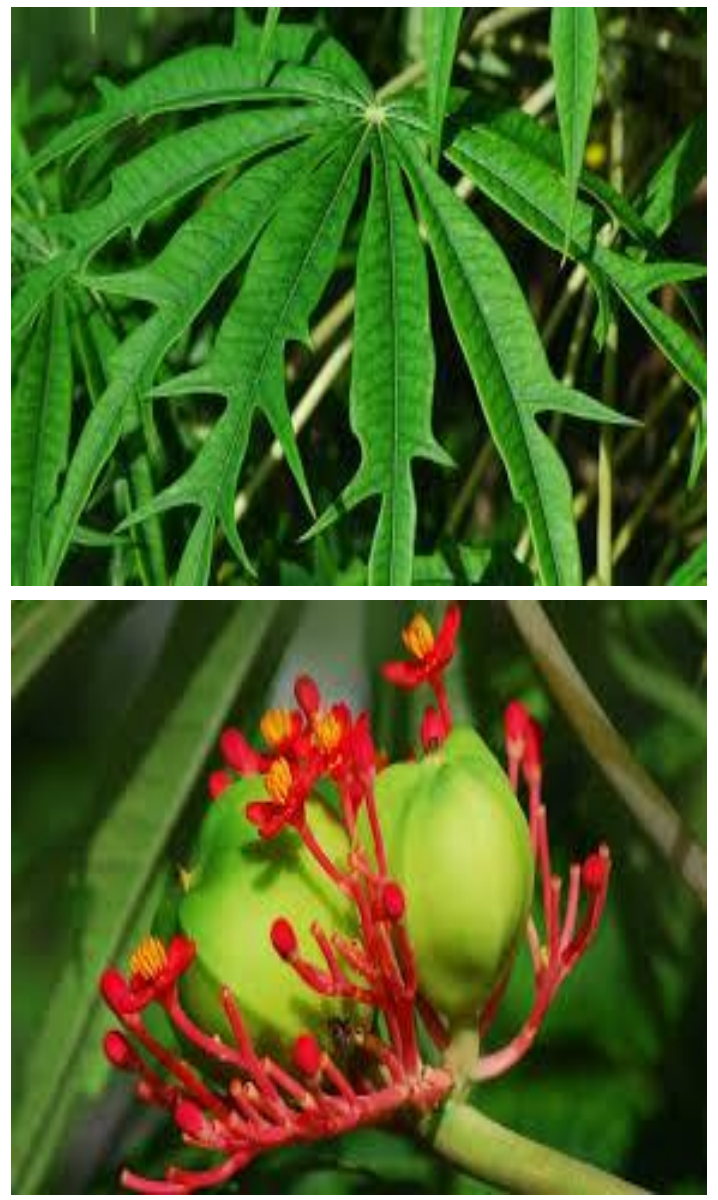

Gambar 13. Bentuk daun, bunga dan buah Jatropha multifida

Studi fitokimia dari berbagai spesies Jatropha mengungkapkan adanya kandungan alkaloid, cardiac-glycoside, flobatannis, flavonoid, tannin dan saponin (Beatrize C. et al., 2012).Bagian daun dari Jatropha multifida dan Jatropha podagrica memiliki komponen flavonoid, phenolic acid, glycoflavones, 
proanthocyanidin dan steroid. Kandungan flavonoid pada Jatropha multifida terdeteksi sebagai vanilic, syringic, p-OH Benzoic acid, cis dan trans ferulic, $p$-coumaric dan phloretic acid (Sallykutty Thomas, 2016).

\subsection{Pewarnaan Hematoxilin Eosin}

Sebagian besar sel dan ECM sepenuhnya tidak berwarna dan untuk mempelajari secara mikroskopik setiap bagiannya diperlukan pewarnaan. Metode pewarnaan tidak hanya membuat berbagai komponen jaringan terlihat kontras namun juga dapat membedakan komponen sel. Jaringan dengan negative charge (anionik) seperti asam nukleat memerlukan basic dye yang disebut basophilic, sedangkan komponen kation seperti seperti protein dengan berbagai grup asam amino yang terionisasi mempunyai affinitas pada aciditas dye yang disebut acidophilic (Anthony L. Mescher, 2013)

\section{Metode Penelitian}

Penelitian ini merupakan penelitian post test only control dengan eksperimental murni laboratorium. Sampel menggunakan tikus Rat norvegicus jantan dengan pertimbangan tidak ada pengaruh hormonal, sebanyak 24 ekor. Tehnik pengambilan sampel dilakukan secara alokasi random dan penelitian dibagi menjadi 4 kelompok dan masing-masing kelompok berisi 6 ekor tikus yang telah diberi perlukaan pada mukosa mulut dan telah diberi pakan standard dan aquadest yang sama. Kelompok tikus terdiri dari kelompok K0 (kelompok dengan terapi CMC-Na3\% secara topikal), P1 (kelompok dengan terapi ekstrak gel Jatropha multifida 2,5\%), P2 (kelompok dengan terapi ekstrak gel Jatropha multifida 5\%), P3 (kelompok dengan terapi ekstrak gel Jatropha multifida 10\%).

Peralatan yang digunakan dalam penelitian terdiri dari perlengkapan perawatan tikus putih (kandang dan pakan standart), burnisher yang sudah dimodifikasi, pinset chirurgis, bejana maserasi, gelas ukur, gunting bedah, cotton buds, burner, handscoon, botol pot untuk tempat specimen jaringan dan mikroskop. Bahan yang digunakan dalam penelitian ini antara lain tanaman Jatropha multifida yang didapatkan di kota Kediri, aquadest, CMC-Na 3\%, alkohol, buffer formalin $10 \%$ dan bahan untuk pewarnaan Hematoxylin eosin. Setelah tikus Rat norvegicus diadaptasi selama 1 minggu selanjutnya dilakukan pembagian kelompok secara random. Kelompok tikus diberikan anestesi Ketamin supaya tidak mengalami rasa sakit saat dibuat perlukaan pada mukosa mulut.

Pembuatan ulcer atau perlukaan pada mukosa mulut tikus dilakukan dengan menggunakan burnisher yang sudah dimodifikasi sehingga bisa didapatkan perlukaan yang homogen. Alat burnisher dipanaskan selama satu menit dengan menggunakan nyala api lampu spirtus kemudian disentuhkan ke mukosa labial bawah tikus Rat norvegicus selama 1 detik. Ulcer akan terbentuk setelah 2 hari. Pemberian ekstrak Jatropha multifida diberikan secara topikal pada hari ke-3 setelah ulcer terbentuk dengan gambaran klinis eritema diperifer dan bagian tengah berwarna putih kekuningan. Setiap kelompok diberikan terapi 2 kali sehari secara topikal pada bagian ulcer dengan menggunakan cutton bud hingga hari ke-5. Pada hari ke-6 semua kelompok dikorbankan, dilakukan biopsi incise, kemudian potongan jaringan diletakkan pada kertas saring yang sudah dipersiapkan dan ditutup sedemikian rupa agar jaringan mukosa bibir tikus Rat norvegicus tidak terlipat ketika direndam buffer formalin $10 \%$.

Pewarnaan yang dilakukan adalah pewarnaan Hemotoxylin eosin yang digunakan untuk menghitung jumlah fibroblast di setiap preparat kelompok tikus dengan menggunakan graticulae dan dilihat dibawah mikroskop dengan pembesaran 400x.

\section{HASIL DAN PEMBAHASAN}

\subsection{Hasil Penelitian}

Dari hasil perhitungan jumlah fibroblast di setiap kelompok didapatkan rerata jumlah fibroblast hari ke-5 dengan konsentrasi ekstrak Jatropha multifida 5\% menunjukkan proses penyembuhan yang terkendali. Sedangkan jumlah fibroblast pada hari ke-3 pada setiap 
kelompok perlakuan memperlihatkan jumlah fibroblast lebih tinggi dibandingkan pada kelompok kontrol.

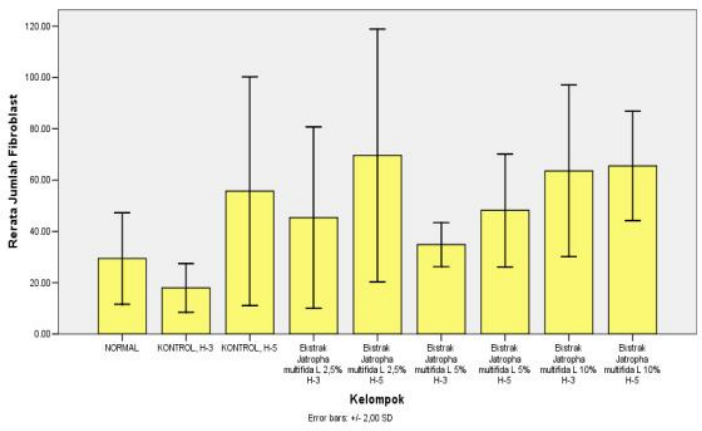

Gambar 14. Distribusi dan rerata jumlah fibroblast

Tabel 1. Hasil Uji Normalitas

\begin{tabular}{ccc}
\hline Kelompok & \multicolumn{2}{c}{ Jumlah Fibroblast } \\
& Hari ke-3 & Hari ke-5 \\
K0 (kontrol) & 0,934 & 0,743 \\
P1 (JM 2,5\%) & 0,758 & 0,970 \\
P2 (JM 5\%) & 0,978 & 0,995 \\
P3 (JM 10\%) & 0,971 & 0,618 \\
\hline
\end{tabular}

Hasil kolomogrov-smirnov test seperti pada tabel diatas menunjukkan bahwa jumlah fibroblast dari tiap kelompok yang diuji adalah berdistribusi normal. Hal ini terlihat dari besarnya nilai $\mathrm{P}$ dari tiap kelompok > 0,05.

Dari hasil data jumlah fibroblast diatas menunjukan bahwa pada hari ke-3 secara rerata menunjukkan adanya perbedaan signifikan diantara kelompok kontrol dan kelompok perlakuan. Pada hari ke-5 secara statistik terdapat perbedaan yang signifikan $(\mathrm{p}<0,05)$ diantara kelompok kontrol dan kelompok perlakuan namun secara rerata tidak ada perbedaan signifikan jumlah fibroblast pada kelompok kontrol dan kelompok perlakuan.
Tabel 2. Hasil uji beda variabel jumlah fibroblast

\begin{tabular}{cccc}
\hline Kelompok & $\begin{array}{c}\text { Jumlah } \\
\text { Fibroblast } \\
\text { Hari ke-3 }\end{array}$ & $\begin{array}{c}\text { Jumlah } \\
\text { Fibroblast } \\
\text { Hari ke-5 }\end{array}$ & $\begin{array}{c}\text { Harga } \\
\text { (uji } 2)\end{array}$ \\
& $17,97 \pm 4,73$ & $55,70 \pm 22,29^{\mathrm{bc}}$ & - \\
K0 & $45,37 \pm 17,70$ & $69,60 \pm 24,61^{\mathrm{b}}$ & 0,079 \\
P1 & $34,83 \pm 4,30$ & $48,20 \pm 11,00^{\mathrm{c}}$ & $0,020^{*}$ \\
P2 & $65,37 \pm 16,74$ & $65,53 \pm 10,62^{\mathrm{bc}}$ & 0,813 \\
P3 & $<0,0001$ & 0,003 & \\
P & & & \\
(Anova) & & & \\
\hline
\end{tabular}

Keterangan: Berbeda huruf superskrip menunjukkan adanya perbedaan bermakna menggunakan uji komparasi berganda LSD (harga $\mathrm{p}<0,05$ ).

\subsection{Pembahasan}

Hasil data penelitian hitung jumlah fibroblast pada hari ke-3 secara statistik menunjukkan adanya perbedaan signifikan di setiap kelompok berdasarkan uji anova $(\mathrm{p}<0,05)$ namun secara rerata didapatkan jumlah fibroblast lebih tinggi dikelompok perlakuan dibandingkan kelompok kontrol.

Hal ini menunjukkan bahwa ekstrak Jatropha multifida mampu menstimulasi proliferasi dan migrasi dari sel fibroblast. Mengikuti luka, fibroblast yang berada di sekeliling jaringan akan terstimulasi untuk aktif pada hari ke-3. Sel ini bermigrasi ke area luka karena tertarik oleh faktor TGF- $\beta$ dan PDGF yang dilepaskan oleh sel inflamasi dan trombosit. Fibroblast pertama terlihat di area luka di hari ke-3 setelah luka dan akumulasi fibroblast memerlukan modulasi fenotip. Sekali sel fibroblast berada di area luka maka sel fibroblast akan berproliferasi sebanyakbanyaknya dan membentuk matrik yaitu hyaluronan, proteoglikan serta kolagen tipe 1 dan 3. Semua produk dari fibroblast diendapkan di lingkungan lokal setempat ( $\mathrm{T}$. Velnar et al., 2009). 
Hasil hitung jumlah fibroblast pada hari ke-5 didapatkan perbedaan yang signifikan diantara setiap kelompok berdasarkan uji anova $(\mathrm{p}<0,005)$, dimana kelompok kontrol berbeda dengan kelompok perlakuan P1 dan P2 namun tidak ada perbedaan dengan kelompok P3. Dari penelitian sebelumnya tentang TGF- $\beta$ (Sahrah, 2016) diketahui bahwa komponen bioaktif dalam ekstrak Jatropha multifida mampu meningkatkan ekspresi TGF- $\beta$.

Induksi TGF- $\beta$ mampu memberikan signal kritis dan kontrol utama yang akan meregulasi fungsi fibroblast dan meningkatkan transkripsi gen untuk pembentukan kolagen, proteoglikan dan fibronektin sehingga terjadi peningkatan produksi protein pada matrik. Fungsi utama dan esensial dari fibroblast selama penyembuhan luka adalah memproduksi matrik ekstra selular baru untuk memperbaiki jaringan yang rusak serta sebagai sel 'sentinel' yang memonitor homeostasis jaringan ikat (Matthias Chiquet et al., 2015).

Data hasil penelitian uji beda hitung jumlah fibroblast antara hari ke-3 dan hari ke5 didapatkan secara rerata jumlah fibroblast lebih tinggi di hari ke-5 di kelompok kontrol dan di setiap kelompok perlakuan P1, P2 dan P3. Hal ini menunjukkan bahwa terapi ekstrak Jatropha multifida dengan kandungan aktif Flavonoid mampu menstimulasi makrofage untuk mensekresikan TGF- $\beta$ sehingga berpengaruh terhadap proliferasi, migrasi dan differensiasi sel fibroblast. Konsentrasi ekstrak Jatropha multifida di 5\% menunjukkan jumlah fibroblast lebih tinggi secara signifikan, hal ini menunjukkan pengaruh terhadap proses penyembuhan yang lebih baik.

Sel fibroblast merupakan sel yang bertanggung jawab untuk produksi kolagen, retikular, serat fiber, sintesis glikosaminoglikan dan glikoprotein yang merupakan substansi interselular dan juga sel yang mensintesis MMP, enzim yang bertanggung jawab untuk perubahan kolagen dan serat elastin. Oleh karena itu aktifitas fibroblast memerlukan kontrol yang baik. Kontrol yang tidak tepat di berbagai langkah proses aktifitas fibroblast akan menghasilkan sintesis yang secara kuantitatif berlebihan atau inadequate, secara kualitatif produk yang tidak sempurna menunjukkan adanya proses penyakit seperti scleroderma, keloid, fibrosis atau premature aging (E.J.Mazyala, 2008).

\section{KESIMPULAN DAN SARAN}

\subsection{Kesimpulan}

Berdasarkan penelitian ini diperoleh hasil bahwa pemberian ekstrak Jatropha multifida dapat mempengaruhi jumlah fibroblast, dan dapat disimpulkan bahwa pemberian ekstrak Jatropha multifida berpengaruh secara signifikan terhadap jumlah fibroblast yang lebih tinggi pada konsentrasi 5\% untuk dapat mempengaruhi proses penyembuhan berjalan dengan lebih baik pada aphthous ulcer mukosa mulut tikus Rat norvegicus.

\subsection{Saran}

Ekstrak daun Jarak tintir (Jatropha multifida) dengan komponen bioaktif yang terdapat didalamnya terbukti mampu untuk mempengaruhi proses penyembuhan aphthous ulcer pada mukosa mulut tikus Rat norvegicus. Penelitian ini diharapkan untuk dapat dikembangkan pada penelitian dengan melihat Matrix Metalloproteinase sebagai kelanjutan penelitian dari hitung jumlah fibroblast.

Matrix metalloproteinase yang merupakan regulator kunci dihubungkan dengan perubahan extra cellular matrix.

\section{DAFTAR PUSTAKA}

Adesola A, Adetunji O., 2007.Tersedia dalam jurnal Ekstraksi zat aktif antimikroba dari tanaman yodium (Jatropha Multifida Linn) sebagai bahan baku alternatif antibiotik alami oleh Sari FM\&Sari SM. hal: 1

Anabel Diaz et al., 2015. Behaviour of The Recurrent Aphthous Stomatitis as a Dental Urgency at Vedado's University Policlinic. Faculty of Dental Medicine, University of Porto Portugal Original Research. 
Al Samadi et al., 2015. Epithelial Cell Apoptosis in Recurrent Aphthous Ulcer. Journal of dental research. Vol.94 (7) 928-935. Institute of Clinical Medicine Biomedicum, Helsinki, Finland.

Anthony L. Mescher, 2013. Basic Histology Text and Atlas. Thirteenth edition. Medical McGraw Hill eBook. Indiana

Beatrize C.K. Hirota et al., 2012. C- Glycosyl Flavones and Comparative Study of The Antioxidant, Haemolytic and Toxic Potential of Jatropha multifida Leaves and Bark. International Journal of Phytomedicine 4. 01 - 05. Brazil.

Christian Agyare, Yaw Duah Boakye, 2015. African Medicinal Plants With Wound Healing Properties. Journal of Ethnopharmacology Institute for Pharmaceutical Biology and Phytochemistry, University of Munster, Germany.

E. J. Mazyala, 2008. Dermal Fibroblast : A Histological And Tissue Culture Study. Division of anatomy and histology, faculty of health science, University of Stellenbosch, Mwanza, Tanzania.

Hannu Larjava, 2012. Oral Wound Healing : Cell Biology and Clinical Management, Faculty of Dentistry, University of British Columbia, Vancouver - Canada.

Ian A. Darby, Tim D. Hewitson, 2007. A Survey of Cell Biology : Fibroblast Differentiation in Wound Healing and Fibrosis. The Royal Melbourne Hopital and Department of Medicine.

Laurel M. Morton, Tania J. Phillip , 2016. Wound Healing and Treating Wounds. Differential diagnose and evaluation of chronic wounds. University School of Medicine, Boston. American Academy of Dermatology.

Matthias Chiquet, Christos Katsaros, Dimitris Kletsas, 2015. Multiple Function of Gingival and Mucoperiostal Fibroblasts in Oral Wound Healing and Repair. Periodontology 2000, Vol. 68, 2015, 21- 40. John Wiley \& Sons, Singapore.
Nwokocha, Blessing A, Agbagwa IO and Okoli BE., 2011. Comparative Phytochemical Screening of Jatropha L. Species in the Niger Delta.Research Journal of Phytochemistry. 5(2): 107114

Nicholas S. Greaves et al., 2013. Current Understanding of Molecular and Cellular Mechanism in Fibroplasia and Angiogenesis During Acute Wound Healing. Journal of Dermatological Science - Elsevier.

P. Bainbridge, 2014. Wound Healing and The Role of Fibroblast. Journal of Wound care. Vol 22 no 8, 407 - 8/ 410-12. Biomedical Chemistry, Cardiff University, UK.

Ronald G. Shashy, Marion B. Ridley, 2000. Aphthous Ulcer : A difficult Review Article. Clinical entity Am.J. Otolaryngol 2000; 21: 389-393. Saunders Company.

Salkutty Thomas, 2016. Pharmacognostic and Phytochemical Constituent of Leaves of Jatropha multifida Linn and Jatropha podagrica Hook. Journal of Pharmacognosy and Phytochemistry 2016; 5 (20: 243-246. India.

Sean E.Gill, William C. Parks, 2008. Metalloproteinases and Their Inhibitor: Regulator of Wound Healing. Int. J. Biochem Cell Biol. 2008; 40 (6-7): 1334 - 1347. University of Washington, Seattle, WA.

Silma Rampadarath, Daneshwar Puchoa, Vijayanti Mala, 2014. Antimicrobial, Phytochemical and Larvicidal Properties of Jatropha multifida Linn. Asian Pasific Journal of Tropical Medicine. Faculty of Agriculture, University of Mauritius - Elsevier.

S. Kosasih et al., 1989. Labaditin, A Novel Cyclic Decapeptide from The Latex of Jatropha multifida. Vol 256, number 1,2, 91-96. Elsevier Science Publisher Biomedical Division.

Sophie Van Lithout, Kapka Miteva, Carsten Tschope, 2014. Crosstalk Between Fibroblast and Inflammatory Cells. Cardiovascular Research (2014) 102, 
Jurnal Biosains Pascasarjana Vol. 19 (2017) pp

(C) (2017) Sekolah Pascasarjana Universitas Airlangga, Indonesia

258-259. European Society of Cardiology.

Stephen T. Sonis, 2015. Genomic, Personalized Medicine and Oral Disease. Springer International Publishing Switzerland, 2015.

Sule Coskun, Emine Gulceri Gulec, Barbaros Balabanli, 2007. Effect of Epidermal Growth Factor on Lipid Peroxidation and Nitric Oxide Level in Oral Mucosal Ulcer Healing. A time course study Surg today (2007) 37; 570-574 Gazi University, Ankara - Turkey.

Sunday O. Akintoye, Greenberg MS., 2014. Reccurrent Aphthous Stomatitis. Dent Clin N. Am 2005;49;31-47. School of Dental Medicine, University Of Pennsylvania, Philadelphia.

Shruti Shukla et al.,2012. Plants as Potential Sources of Natural Immuno modulators. Rev.Environ Sci Biotechnol, Mini review. Springer, 2012.

T. Velnar, T. Bailey, V. Smrkolj, 2009. The Wound Healing Process : An Overview of The Cellular and Molecular Mechanism. Journal of International Medical Research 2009 37: 1528. Published by SAGE.

Xiao Wen Jiang et al., 2013. Double Blind, Randomized, Controlled Clinical Trial of The Effects of Diosmetite and Basic Fibroblast Growth Factor Paste On Treatment of Minor Recurrent Aphthous Stomatitis. Oral Surg Oral Med Oral Pathol Oral Radiol 2013; 116:570-575. University Of South China, Chenzou, Hunan, China. 